\title{
Evaluation of a new Argovit as an antiviral agent included in feed to protect the shrimp Litopenaeus vannamei against White Spot Syndrome Virus infection
}

\author{
Carlos R Romo Quiñonez ${ }^{1}$, Ana R Álvarez Sánchez ${ }^{2}$, Pindaro Álvarez-Ruiz ${ }^{3}$, Maria C Chávez Sánchez ${ }^{4}$, Nina \\ Bogdanchikova $^{5}$, Alexey Pestryakov ${ }^{6}$, Claudio H Mejia-Ruiz ${ }^{\text {Corresp. } 7}$ \\ ${ }^{1}$ Laboratorio Biotecnologia de Organismos Marinos, Programa de Acuicultura, Centro de Investigaciones Biológicas del Noroeste, La Paz, BCS, México \\ 2 Universidad Técnica Estatal de Quevedo, Quevedo, Los Rios, Ecuador \\ 3 Departamento de Acuicultura, Centro Interdisciplinario de Investigación para el Desarrollo Integral Regional, I.P.N., Guasave, Sinaloa, México \\ 4 Unidad de Acuicultura y Manejo Ambiental, Centro de Investigación en Alimentación y Desarrollo, Mazatlan, Sinaloa, México \\ 5 Centro de Nanociencias y Nanotecnología, Universidad Nacional Autonoma de Mexico, Ensenada, Baja California, México \\ 6 Tomsk Polytechnical University, Tomsk, Russia \\ 7 Laboratorio Biotecnología de Organismos Marinos, Programa de Acuicultura., Centro de Investigaciones Biológicas del Noroeste, La Paz, BCS, México \\ Corresponding Author: Claudio H Mejia-Ruiz \\ Email address: hmejia04@cibnor.mx
}

In this study, four experimental assays were conducted to evaluate the use of a new silver nanoparticle formulation named Argovit-4, which was prepared with slight modifications to enhance its biological activity against white spot syndrome virus (WSSV) in shrimp culture. The goals of these assays were to (1) determine the protective effect of Argovit-4 against WSSV, (2) determine whether Argovit-4 supplemented in feed exhibits toxicity towards shrimp, (3) determine whether Argovit-4 as antiviral additive in feed can prevent or delay/reduce WSSV-induced shrimp mortality, and (4) determine whether Argovit-4 supplemented in feed alters the early stages of the shrimp immune response. In bioassay 1, several viral inocula calibrated at 7 shrimp infectious doses (SID) were exposed to 40 , 100, 200 and $1000 \mathrm{ng} / \mathrm{SID}$ of $\mathrm{Ag}+$ and then intramuscularly injected into shrimp for $96 \mathrm{~h}$. In assay 2, shrimp were fed Argovit-4 supplemented in feed at different concentrations (10, 100 and $1000 \mu \mathrm{g}$ per gram of feed) for $192 \mathrm{~h}$. In assay 3, shrimp were treated with Argovit-4 supplemented in feed at different concentrations and then challenged against WSSV for $192 \mathrm{~h}$. In bioassay 4, quantitative real-time RT-qPCR was performed to measure the transcriptional responses of five immune-relevant genes in the haemocytes of experimental shrimp treated with Argovit-4 supplemented in feed at 0, 6, 12, 24 and $48 \mathrm{~h}$. The intramuscularly injected Argovit-4 showed a dose-dependent effect $(p<0.05)$ on the cumulative shrimp mortality from 0-96 h post-infection. In the second bioassay, shrimp fed Argovit-4 supplemented in feed did not show signs of toxicity for the assayed doses over the 192-h experiment. The third and fourth bioassays showed that shrimp challenged with 
WSSV at $1000 \mu \mathrm{g} / \mathrm{g}$ feed exhibited reduced mortality without altering the expression of some immune system-related genes according to the observed level of transcriptional. This study is the first show that the new Argovit-4 formulation has potential as an antiviral additive in feed against WSSV and demonstrates a practical therapeutic strategy to control WSSV and possibly other invertebrate pathogens in shrimp aquaculture. 


\section{Evaluation of a new Argovit as an antiviral agent}

\section{2 included in feed to protect the shrimp Litopenaeus}

3 vannamei against White Spot Syndrome Virus

4 infection

5

6

Carlos Rosendo Romo-Quiñonez ${ }^{1}$, Ana Ruth Álvarez-Sánchez², Píndaro Alvarez-Ruiz ${ }^{3 *}$, María Cristina Chávez-Sanchez ${ }^{4}$, Nina Bogdanchikova ${ }^{5}$, Alexey Pestryakov ${ }^{6}$, Claudio Humberto Mejía-Ruiz ${ }^{1 *}$

1. Laboratorio Biotecnología de Organismos Marinos, Centro de Investigaciones Biológicas del Noroeste, S. C. La Paz, B.C.S. México.

2. Universidad Técnica Estatal de Quevedo. Quevedo, Los Ríos, Ecuador.

3. Departamento de Acuicultura, Centro Interdisciplinario de Investigación para el Desarrollo Integral Regional, I.P.N. Guasave, Sinaloa. México.

4. Unidad de Acuicultura y Manejo Ambiental, Centro de Investigación en Alimentación y Desarrollo, A.C. Mazatlán, Sinaloa. México.

5. Centro de Nanociencias y Nanotecnología, Universidad Nacional Autónoma de México, Ensenada, México.

6. Tomsk Polytechnic University, Tomsk, Russia.

*Corresponding Author 1:

Claudio Humberto Mejía-Ruíz, IPN 195, Col. Playa Palo de Santa Rita Sur, La Paz, B.C.S., 23096, México

Email address: hmejia04@,cibnor.mx

*Corresponding Author 2:

Píndaro Álvarez-Ruiz

E-mail: pindaroalvarez@hotmail.com

\section{Abstract}

In this study, four experimental assays were conducted to evaluate the use of a new silver nanoparticle formulation named Argovit-4, which was prepared with slight modifications to enhance its biological activity against white spot syndrome virus (WSSV) in shrimp culture. The 
34 goals of these assays were to (1) determine the protective effect of Argovit-4 against WSSV, (2)

35 determine whether Argovit-4 supplemented in feed exhibits toxicity towards shrimp, (3)

36 determine whether Argovit-4 as antiviral additive in feed can prevent or delay/reduce WSSV-

37 induced shrimp mortality, and (4) determine whether Argovit-4 supplemented in feed alters the

38 early stages of the shrimp immune response. In bioassay 1, several viral inocula calibrated at 7

$39 \mathrm{SID}_{50}$ (shrimp infectious doses 50\% endpoint) were exposed to 40, 100, 200 and $1000 \mathrm{ng} / \mathrm{SID}_{50}$

40 of $\mathrm{Ag}^{+}$and then intramuscularly injected into shrimp for $96 \mathrm{~h}$. In bioassay 2, shrimp were fed

41 Argovit-4 supplemented in feed at different concentrations (10, 100 and $1000 \mu \mathrm{g}$ per gram of

42 feed) for 192 h. In bioassay 3, shrimp were treated with Argovit-4 supplemented in feed at

43 different concentrations and then challenged against WSSV for $192 \mathrm{~h}$. In bioassay 4, quantitative

44 real-time RT-qPCR was performed to measure the transcriptional responses of five immune-

45 relevant genes in haemocytes of experimental shrimp treated with Argovit-4 supplemented in

46 feed at 0, 6, 12, 24 and 48 h. The intramuscularly injected Argovit-4 showed a dose-dependent

47 effect $(\mathrm{p}<0.05)$ on the cumulative shrimp mortality from $0-96 \mathrm{~h}$ post-infection. In the second

48 bioassay, shrimp fed Argovit-4 supplemented in feed did not show signs of toxicity for the

49 assayed doses over the 192-h experiment. The third and fourth bioassays showed that shrimp

50 challenged with WSSV at $1000 \mu \mathrm{g} / \mathrm{g}$ feed exhibited reduced mortality without altering the

51 expression of some immune system-related genes according to the observed level of

52 transcriptional. This study is the first show that the new Argovit-4 formulation has potential as an

53 antiviral additive in feed against WSSV and demonstrates a practical therapeutic strategy to

54 control WSSV and possibly other invertebrate pathogens in shrimp aquaculture.

55

56 Keywords: Feed additive; AgNPs; Shrimp; WSSV; Gene expression

57

58 Introduction

59 The white spot syndrome virus (WSSV) is highly aggressive towards shrimp aquaculture

60 worldwide, for which several studies have attempted to develop a treatment (Álvarez-Sánchez et

61 al., 2018). This pathogen can cause 100\% mortality in shrimp culture in just a few days, causing

62 large economic losses, business closures and high unemployment rates (Sánchez-Martínez,

63 Aguirre-Guzmán \& Mejía-Ruíz, 2007; Bustillo, Escobedo \& Sotelo, 2009). Currently,

64 nanotechnology has attracted a great deal of attention as an emerging field of research and 
65 technological development that open the possibility of handling material at the nanometric level, 66 with dimensions between 1 and $100 \mathrm{~nm}$ (Meneses-Marquez et al., 2018). In this size range, 67 nanoparticles show new physical and chemical properties that can be used in different scientific 68 areas for the unprecedented study of phenomena that occur at the atomic and molecular level 69 (Parveen, Misra \& Sahoo. 2012; Esmaeillou et al., 2017). Among the most interesting and 70 promising nanomaterials are silver nanoparticles (AgNPs), which have shown broad-spectrum 71 antiviral activity (Bello-Bello et al., 2018; Galdiero et al., 2011; Chris, Singh \& Agarwal. 2018). 72 Several in vitro studies have demonstrated the effect of AgNPs as an antiviral alternative against 73 human viruses, including human immunodeficiency virus (Elechiguerra et al., 2005; Lara et al., 74 2010), H1N1 influenza A virus (Mori et al., 2013), monkeypox virus (Rogers et al., 2008), 75 Tacaribe virus (Speshock et al., 2010), hepatitis B virus (Leu et al., 2008) and herpes simplex 76 virus (Baram-Pinto et al., 2009).

77 The mechanism of action of AgNPs as an antiviral agent has been studied against several 78 enveloped viruses (Lara et al., 2011; Bogdanchikova et al., 2016), and it has suggested that 79 AgNPs undergo preferential binding with viral envelope glycoproteins to inhibit viruses from 80 binding to host cells (Elichiguerra et al., 2005; Lara et al., 2010). In addition, multiple studies 81 have shown that nanoparticles can be recognized by the immune system and modulate the 82 induction of immunostimulatory effects (Dacoba et al., 2017; Boraschi et al., 2017).

83 Recent advances have been made in aquaculture using AgNP-based formulations. In one study, 84 Argovit ${ }^{\circledR}$ that was administered intramuscularly in shrimp Litopenaeus vannamei showed 85 antiviral activity against WSSV (Juarez-Moreno et al., 2017), a highly lethal and contagious 86 pathogen. This result indicated that a single dose of silver nanoparticles was able to increase shrimp survival by up to $80 \%$ without toxic effects. In another study, Ochoa-Meza et al. (2019) evaluated the ability of silver nanoparticles coated with commercial non-toxic PVP (Argovit $®$ ) to promote the immune system response of shrimp infected with WSSV and observed a late immunostimulatory activity of two immune-related genes. In the same report, authors showed that a single dose of AgNP was able to increase the survival of the shrimp against severe infections of WSSV, even under adverse conditions in the presence of a high concentration of 93 ferrous ions.

94 Crustaceans have an innate immune system, similar to other invertebrates, however, they lack a 95 developed adaptive immune system. The innate immune system of shrimp consists of several 
96

97

98

99

100

101

102

103

104

105

106

107

108

109

110

111

112

113

114

115

116

117

118

119

120

121

122

123

124

125

126

127

natural defence mechanisms: a microbial recognition system, a prophenoloxidase system (proPO system), a coagulation system, phagocytosis, encapsulation and the formation of nodules and oxygen reactive compounds (Kurtz, 2005; Ji, Xiao \& Wang, 2009; Hirono, et al., 2011). Several genes that participate in the shrimp immune system have been described in the species $L$. vannamei, some of which have been described in previous reports from our group (Flegel \& Sritunyalucksana, 2010). To identify a potential mechanism of the antiviral and immunostimulatory activities of silver nanoparticles in shrimp, we selected five genes to study that are representative of different immunological routes. Two of the genes encode proteins (Rab6 and PAP) that participate in endocytosis and phagocytosis (Ye, Tang \& Zhang 2012; Khimmakthong et al., 2013). The genes encoding Crustin and PEN4 have been identified as participating in antiviral immunity against WSSV infections in L. vannamei (Sun et al., 2017; Xiao et al., 2018). Finally, the proPO gene activates the proPO system, which is involved in melanin formation in arthropods and other invertebrates (Sritunyalucksana \& Soderhall, 2000) and results in the production of the melanin pigment that can often be seen as dark spots in the cuticle of arthropods and two antimicrobial peptides from defence system also in WSSV infections (Abad-Rosales et al., 2019). These advances have demonstrated that AgNPs are effective against a wide spectrum of viruses, especially against the disease-causing WSSV, for which there have been no effective treatments until now (Verbruggen et al., 2016). However, intramuscular administration of AgNPs is impractical, considering the large volumes of organisms to that would need to be treated. A practical alternative is the inclusion of AgNPs in balanced shrimp feed (Dananjaya et al., 2016), guaranteeing a greater usefulness of AgNPs therapy.

Although the Argovit ${ }^{\circledR}$ formulation is no longer commercially available, new formulations have been developed with unique features (N. Bogdanchikova, Personal communication, December 2017). For instance, the Argovit-4 formulation retains essentially same the silver nanoparticle design of Argovit ${ }^{\circledR}$. Thus, in this study, we investigated whether the AgNPs-based Argovit-4 could be used as an antiviral additive in feed to interfere with WSSV infection in shrimp.

\section{Materials and Methods} Argovit-4 formulation

The silver nanoparticles Argovit-4, which replaced Argovit ${ }^{\circledR}$ (Novosibirsk, Russia; patent 2427380) was kindly donated by Dr. Nina Bogdanchikova from CNyN-UNAM, and this can be 
128 requested by contacting Dr. Bodganchikova, (or it can be purchased at Bionag SAPI de CV, 129 Tijuana, México. MC Martha Alvarado, (52) 664-317-99-21). The supplier's specifications 130 indicate that Argovit-4 consists of spherical AgNPs with an average size of $35 \pm 15 \mathrm{~nm}$ that are 131 functionalized with non-toxic PVP (K30) in water. Table 1, which was modified from Juarez132 Moreno et al. (2017), summarizes the physicochemical characterization of these formulations. 133

\section{White spot syndrome viral stock}

135 The WSSV strain (Guasave isolate, 2005) used in this study was kindly provided by the 136 Biochemistry and Molecular Biology Laboratory from CIIDIR, Sinaloa, Mexico. The viral 137 inoculum was prepared according to the methodology described by Alvarez-Ruiz et al. (2013).

138 Muscular tissues from moribund shrimp were collected, weighed and homogenized in 10 139 volumes (W/V) of phosphate-buffered saline (1× PBS; $137 \mathrm{mM} \mathrm{NaCl}, 2.7 \mathrm{mM} \mathrm{KCl}, 10 \mathrm{mM}$ $140 \mathrm{Na}_{2} \mathrm{HPO}_{4}$, and $2 \mathrm{mM} \mathrm{KH}_{2} \mathrm{PO}_{4}$ ) to $\mathrm{pH}$ 7.4. The homogenized tissue was centrifuged at 13,000 $\mathrm{g}$ 141 (or g-force) for $20 \mathrm{~min}$ at $4^{\circ} \mathrm{C}$, after which the supernatant was transferred to another microtube $142(1.6 \mathrm{~mL})$ and centrifuged again at $13,000 \mathrm{x} g$ for $20 \mathrm{~min}$ at $4^{\circ} \mathrm{C}$. The supernatant was passed 143 through a $0.45 \mu \mathrm{m}$ pore-sized filter and stored at $-70^{\circ} \mathrm{C}$.

\section{Preparation of inoculum from WSSV-infected tissue}

146 The experimental challenge with WSSV was conducted by the oral route using infected tissue.

147 The infected tissue was prepared by intramuscularly injecting a batch of shrimp ( $\mathrm{n}=10)$ of $10 \pm 2 \mathrm{~g}$ 148 with of 32 SID $_{50}$ in $100 \mu \mathrm{L}$ of PBS (assuming that $100 \%$ of organisms would be infected at $54 \mathrm{~h}$ 149 post-infection). The shrimp with observable clinical signs of WSSV infection were individually 150 separated and stored at $-70^{\circ} \mathrm{C}$ until all of the shrimp became infected. Subsequently, after 151 removing the cephalothorax, pleopods and exoskeleton the muscle tissue of the dead WSSV152 infected shrimp was weighed and homogenized in $120 \mathrm{~mL}$ of marine water for every $24 \mathrm{~g}$ of 153 tissue. The homogenized material was used as the inoculum used for the bioassay 4 .

\section{Shrimps}

Batches of $L$. vannamei $(4 \pm 0.5 \mathrm{~g}$ ) juveniles were obtained from a local farm in Guasave, Sinaloa, Mexico. The shrimps were transported to CIIDIR-IPN and placed in plastic tanks (1000-L capacity) with $500 \mathrm{~L}$ of filtered seawater at 30 PSU (Practical Salinity Units) with constant 
159 aeration. The shrimps were fed ad libitum twice daily with Camaronina ${ }^{\circledR}$ commercial feed 160 (Purina-Cargill LTD, Minnesota, USA) with 35\% protein. Subsequently, the shrimps were 161 verified to be free of WSSV, IHHNV and AHPND by endpoint PCR.

162

\section{Experimental conditions}

164 All experiments were performed in glass tanks (40-L capacity) containing $25 \mathrm{~L}$ of seawater (30 165 PSU) at $27 \pm 1^{\circ} \mathrm{C}$ and continuous aeration with the shrimps acclimatized under these conditions 166 for $24 \mathrm{~h}$ before starting the experiments. The experimental shrimp for bioassay 1 and 2 were fed 167 Camaronina ${ }^{\circledR}$ at $4 \%$ of their body weight, while in bioassays 3, 4 and 5, the shrimp were fed 168 feed supplemented with AgNPs. The uneaten feed and faecal material were removed by 169 siphoning every 2 days with water exchange (50\% volume) during all experimental assays. 170

171 172

173

174

175

176

177

178

179

180

181

182

183

184

185

186

187 188

\section{In vivo viral titration and determination of minimal infectious dose by the} intramuscular route

A batch of shrimp was used to titre the fresh inoculum using the intramuscular injection method described previously by Alvarez-Ruiz et al. (2013) and Apun et al. (2017). The inoculum was titrated by in vivo injecting $100 \mu \mathrm{L}$ of serial dilutions from the original extract $\left(10^{-3}, 10^{-4}, 10^{-5}\right.$ and $10^{-6}$ ) between the $3 \mathrm{rd}$ and 4 th abdominal segments of shrimp ( $\mathrm{n}=5$ shrimp per dilution). The experimental assay was finished at $96 \mathrm{~h}$ post-infection (hpi). The viral titre was calculated using the method of Reed \& Muench (1938), for the concentration of a test substance that produces an effect of interest in half of the test units (50\% tissue culture infectious dose of a virus), which was described as $\mathrm{SID}_{50} / \mathrm{mL}$.

\section{Preparation of Argovit-4 supplemented feed}

Feed supplemented with AgNPs at different concentrations was made according to the modified method of Gutiérrez-Dagnino et al. (2015). Camaronina ${ }^{\circledR} 35 \%$ protein pellets (commercial feed for shrimp) were pulverized in a coffee grinder. Three homogeneous pastes supplemented with Argovit-4 AgNPs (10, 100 and $1000 \mu \mathrm{g} / \mathrm{g}$ feed), sodium alginate ( $20 \mu \mathrm{g} / \mathrm{g}$ feed; Sigma-Aldrich ${ }^{\circledR}$, St. Louis, MO, USA), and distilled water $(0.5 \mathrm{~mL} / \mathrm{g}$ feed $)$ were generated. In the control feed, AgNPs were replaced by distilled water. Subsequently, the pastes were manually pelletized with 
189 a 50-mL disposable syringe (Millipore ${ }^{\circledR}$, Merck, Darmstadt, Germany) and dried for $72 \mathrm{~h}$ at $4{ }^{\circ} \mathrm{C}$ 190 in darkness.

191

\section{BIOASSAYS}

193 Bioassay 1: Determination of the minimum WSSV infectious dose by 194 intramuscular route

195 Bioassay 1 was designed to determine the effective dose of WSSV that is capable of infecting $196100 \%$ of the shrimp (as determined by conspicuous clinical signs, such as a lack of appetite, 197 erratic swimming and conspicuous atypical coloration). Three groups of shrimp (30 organisms 198 per group, $\mathrm{n}=10$ shrimp in three replicates) were intramuscularly inoculated between the 3rd and 199 4th abdominal segment with different WSSV infectious doses $\left(7,10\right.$ and $100 \mathrm{SID}_{50}$ in $100 \mu \mathrm{L}$ of 200 PBS). The control group was a mock inoculation with $100 \mu \mathrm{L}$ of PBS. The mortality of the 201 shrimp in every group was recorded and the bioassay finished was when all of the infected 202 shrimp died.

203

204

\section{Bioassay 2: Inhibition of pathogenicity by the application of a WSSV-Argovit-4} 205 mixture

Several viral inoculums were calibrated at $7 \mathrm{SID}_{50}$ in $100 \mu \mathrm{L}$ volumes and exposed at 40, 100, 207 200 and 1000 ng of Argovit-4. The viral inoculums and Argovit-4 (WSSV + AgNPs) mixtures were incubated for one hour on ice and then intramuscularly injected into 30 shrimp for every group ( $\mathrm{n}=10$ organisms per replicate) for each treatment. The positive control group was inoculated with WSSV (without AgNPs), while the control group was mock-treated with $100 \mu \mathrm{L}$ of PBS. The experiment lasted up to $96 \mathrm{hpi}$, and every six hours the presence of dead organisms,

212 clinical signs and the behaviour of the surviving shrimp were recorded.

\section{Bioassay 3: Toxic effect of Argovit-4 supplemented in feed}

215 The toxic effect of Argovit-4 supplemented in feed at different concentrations was tested first.

216 The experiment consisted of four treatments with three replicates each $(n=10$ shrimp per 217 replicate) that were organized as follows: (1) shrimps receiving feed without AgNPs (control 218 group), (2) shrimps receiving AgNPs at $10 \mu \mathrm{g} / \mathrm{g}$ feed, (3) shrimps receiving AgNPs at $100 \mu \mathrm{g} / \mathrm{g}$ 219 feed, (4) shrimps receiving AgNPs at $1000 \mu \mathrm{g} / \mathrm{g}$ feed. The shrimps were fed twice daily at 4\% of 
220 their body weight. The signs of toxicity (lethargic movement, empty gut or atypical colour 221 change) and cumulative mortality were recorded daily. Previously a toxicity bioassay was carried 222 out by intramuscular route in the shrimp for each of 5 different designs of Argovit, which did not 223 occurred mortality and Argovit-4 was selected (data not shown).

224

225

226

227

228

229

230

231

232

233

234

235

236

237

238

239

240

241

242

243

244

245

246

247

248

249

250

\section{Bioassay 4: Argovit-4 supplemented in feed against WSSV}

For bioassay 4 , the experimental design was performed in triplicate ( $\mathrm{n}=10$ shrimps by replicate).

The shrimp were fed Argovit-4-supplemented feed at 0 and $12 \mathrm{~h}$ for the first and second feedings, respectively. In both cases, the feed weight corresponded to $4 \%$ of the shrimp body weight (4 g/organism). Subsequently, at $24 \mathrm{~h}$, the shrimps were fed the WSSV inoculum (200 mg infected tissue per shrimp). Every shrimp received two daily rations of food corresponding to $4 \%$ of their body weight, and at $12 \mathrm{~h}$ post-treatment with $\mathrm{AgNP}$ in feed were challenged with $200 \mathrm{mg}$ of infected tissue per shrimp for each replicate. The cumulative mortality was recorded twice a day until $192 \mathrm{~h}$.

\section{Bioassay 5: Immunostimulatory activity of Argovit-4 towards immune-related} genes

To determine the immunostimulatory activity of Argovit-4 on shrimp L. vannamei juveniles, a bioassay was established in two glass tanks ( $40 \mathrm{~L}$ ) with $25 \mathrm{~L}$ of seawater and continuous aeration. Two groups ( $\mathrm{n}=12$ shrimp per tank) were treated with either feed supplemented with Argovit-4 (1000 $\mu \mathrm{g} / \mathrm{g})$ or control feed (feed without Argovit-4) at $4 \%$ of their body weight twice daily.

\section{Haemolymph sampling}

Shrimp haemolymph samples from each tank were collected in pools of three to obtain $\sim 400$ $\mu \mathrm{L} /$ shrimp every $0,6,12$ and $48 \mathrm{~h}$ post-treatment. A $1 \mathrm{~mL}$ syringe $(27 \mathrm{G} \times 13 \mathrm{~mm}$ needle) was used for rinsing with $5 \%$ potassium oxalate in isotonic saline $(850 \mathrm{mOsm} / \mathrm{kg})$ to obtain haemolymph from the ventral sinus (base of the first abdominal segment (Apun-Molina et al., 2017; Guemez-Sorhouet et al., 2019). The pools of haemolymph samples were centrifuged at $800 \mathrm{x} g$ for $10 \mathrm{~min}$ at $4^{\circ} \mathrm{C}$, after which the plasma was removed and the pellet was washed with $250 \mu \mathrm{L}$ of cold PBS centrifugation as described above. The supernatant was removed, and the 
251 haemocytes were suspended in microtubes containing $200 \mu \mathrm{L}$ of precooled TRIzol Reagent (TRI 252 Reagent ${ }^{\circledR}$, Molecular Research Center, Ohio, USA). The haemocyte samples were stored at $25370^{\circ} \mathrm{C}$ until use.

254

\section{Isolation of RNA and cDNA synthesis}

256 Total RNA from the haemocyte and intestinal samples was extracted with TRIzol reagent

257

258

259

260

261

262

263

264

265

266

267

268

269

270

271

272

273

274

275

276

277

278

279

280

281

according to the manufacturer's protocol. The RNA was quantified at $260 \mathrm{~nm}$ using a NanoDrop instrument (NanoDrop Technologies, Wilmington, DE) and then treated with DNase $1(1 \mathrm{U} / \mu \mathrm{L}$, Sigma-Aldrich ${ }^{\circledR}$, St. Louis, MO, USA) to remove residual genomic DNA. cDNA synthesis was performed using the Improm II ${ }^{\circledR}$ Reverse Transcription System (Promega, Wisconsin, USA) with $500 \mathrm{ng}$ of total RNA and random primers from the kit. The obtained cDNA was suspended in $80 \mu \mathrm{L}$ of ultrapure water and stored at $-70^{\circ} \mathrm{C}$ until analysis.

\section{Quantitative real-time PCR analysis}

The transcriptional responses of genes encoding immune-related proteins (PEN4, Crustin, proPO, PAP and Rab6) from L. vannamei haemocytes were determined by quantitative real-time PCR (RT-qPCR) using a CFX96 system and CFX Manager version 3.0 (Bio-Rad Laboratories, Hercules, CA, USA). The expression of target genes was normalized to that of the $\beta$-actin gene as an endogenous control. Table 2 shows the sequences of specific primers used in this study. All amplifications were performed (in duplicate) in $15 \mu \mathrm{L}$ volume reactions and contained $7.5 \mu \mathrm{L}$ of PCR master-mix $2 \times(3.0 \mu \mathrm{L}$ of $5 \times$ Colorless GoTaq Flexi Buffer [Promega, Wisconsin, USA], $1.5 \mu \mathrm{L}$ of $25 \mathrm{mM} \mathrm{MgCl}_{2}$ [Promega], $0.3 \mu \mathrm{L}$ of $10 \mathrm{mM}$ dNTPs [Bioline, Taunton, MA, USA], $0.75 \mu \mathrm{L}$ of $20 \times$ EvaGreen ${ }^{\circledR}$ [Biotium, Fremont, CA, USA], $0.1 \mu \mathrm{L}$ of $5 \mathrm{U} / \mu \mathrm{L}$ GoTaq ${ }^{\circledR}$ Flexi DNA Polymerase [Promega, Wisconsin, USA], and $1.85 \mu \mathrm{L}$ of ultrapure water). Each mastermix aliquot was mixed with $0.35 \mu \mathrm{L}$ of each primer (10 $\mu \mathrm{M}$, Sigma-Aldrich $\AA), 1.8 \mu \mathrm{L}$ of ultrapure water and $5 \mu \mathrm{L}$ of cDNA as template. The thermocycling program was as follows: an initial cycle of $95^{\circ} \mathrm{C}$ for $3 \mathrm{~min}$, followed by 40 cycles of $95^{\circ} \mathrm{C}$ for $10 \mathrm{~s}, 58^{\circ} \mathrm{C}$ for $20 \mathrm{~s}, 72^{\circ} \mathrm{C}$ for $30 \mathrm{~s}$ and $79^{\circ} \mathrm{C}$ for $5 \mathrm{~s}$ (to acquire the fluorescence signal). After each reaction, a dissociation curve from 65 to $90^{\circ} \mathrm{C}$ was recorded at $0.5^{\circ} \mathrm{C}$ increments and examined for unique and specific products. The Pfaffl method was used to analyse the relative quantification data from the realtime PCR experiments (Pfaffl, 2003). 
282

\section{Statistical analysis}

284 The percentage data of cumulative mortality (Bioassays 2, 3 and 4) were initially arcsine285 transformed to perform the statistical analysis. Normality and homogeneity of variances 286 assumptions were analysed by Kolmogorov-Smirnov and Levene's tests. Thereafter, Kruskal287 Wallis ANOVA test (non-parametric ANOVA) followed by a multiple comparison test was used 288 to determine significant differences between the experimental groups $(\mathrm{p}<0.05)$.

289 To determine the effect of Argovit-4 on the transcriptional response of five immune-relevant 290 genes (Bioassay 5), the data were Log10-transformed to confirm its normality before statistical 291 analysis. The data were analysed by Student's t-test to determine significant differences $292(\mathrm{p}<0.05)$. All bioassays were performed in triplicate and the results of cumulative mortality were 293 expressed as mean \pm standard deviation. While, the immune-related gene expression results are 294 reported as the mean values \pm standard error. Statistical analyses were performed using 295 STATISTICA version 8.0 (StatSoft, Tulsa, OK).

296

297

Results

298

299

300

A 7 SID $_{50}$ inoculum is the minimum effective dose to generate $100 \%$ shrimp mortality

301 In the challenge bioassay, the three assayed doses of WSSV resulted in 100\% shrimp mortality at 302 different time intervals. The shrimp group infected with 100 SID $_{50}$ showed mortality after 30 hpi 303 with values above $3 \%$, reaching $100 \%$ of mortality at 54 hpi. In contrast, the shrimp group 304 infected with 10 SID $_{50}$ exhibited mortality after 36 hpi with values above $17 \%$, reaching $100 \%$ at 30560 hpi. Finally, in the shrimp group infected with 7 SID $_{50}$, mortality began after 36 hpi with 306 values above 13\%, reaching 100\% at 72 hpi. The control group (PBS) did not show mortality 307 during the bioassay (Fig. 1). The results revealed that 7 SID $_{50}$ as the minimal dose capable 308 causing $100 \%$ of shrimp to be infected with conspicuous clinical signs (lack of appetite, erratic 309 swimming and atypical coloration). 
312 The shrimp group treated with $1000 \mathrm{ng} / \mathrm{SID}_{50}$ showed the lowest mortality $(50 \%)$ at $60 \mathrm{hpi}$,

313 whereas the shrimp groups treated with 40, 100 and $200 \mathrm{ng} / \mathrm{SID}_{50}$ of Argovit-4 showed

314 mortalities of 90,83 and $70 \%$ at 60 hpi, respectively. The positive control showed 100\%

315 mortality at 72 hpi compared with $0 \%$ in the control group. Statistical analysis revealed that the

316 susceptibility of the shrimp to WSSV mixed with Argovit-4 significantly decreased (Kruskal-

317 Wallis test; $\mathrm{p}=0.0169$ ) in a dose-dependent manner across the groups (Fig. 2).

318

319 Argovit-4 supplemented in feed is non-toxic

320 None of the assayed Argovit-4 doses supplemented in feed caused significant shrimp mortality

321 (Kruskal-Wallis test; $p=0.0000$ ) and not affect the health or survival of shrimp, given that they

322 did not show atypical behaviour (evaluated by observations for empty guts, lethargy, and erratic

323 movement) by toxicity effects during the course of the bioassay at $192 \mathrm{~h}$ post-treatment.

324

325

\section{Argovit-4 supplemented in feed has an antiviral effect against WSSV}

326

327

328

329

330

331

332

333

334

335

336

337

338

339

340

\section{Discussion}

342 Several studies have evaluated the effectiveness of AgNPs in aquatic diseases control because to

The shrimp group exposed to infected WSSV tissue (without Argovit-4) showed a mortality of $43 \%$ at 84 hpi. The cumulative mortality in shrimp fed the $1000 \mu \mathrm{g} / \mathrm{g}$ doses was $3 \%$ after infection with WSSV at $192 \mathrm{~h}$, followed by 10 and $16 \%$ for the 100 and $10 \mu \mathrm{g} / \mathrm{g}$ doses, respectively. In contrast, the uninfected control group did not show mortality. Interestingly, statistical analysis (Kruskal-Wallis test; $\mathrm{p}=0.0001$ ) did not reveal a dose-dependent effect (Fig.
3). However, the results revealed an obvious antiviral effect with both doses assayed.

\section{Argovit-4 does not induce an early immunostimulatory effect for immune-related} genes

The expression analysis of genes encoding Crustin, PEN4, PAP and Rab6 showed no significant $(p<0.05)$ changes in the haemocytes of shrimp treated with Argovit-4 supplemented in feed with respect to the control (Fig. 4A, 4B; 5A, 5B). Interestingly, only the gene encoding proPO was downregulated at $48 \mathrm{~h}$ (t-student test; $\mathrm{p}=0.024)$, which was possibly an indirect effect of low levels of AgNPs in the haemolymph (Fig. 6). 
343 their antimicrobial potential against bacteria, virus and parasites (Barakat, El-Sayed \& Gohar,

344 2016; Morales-Covarrubias et al., 2016; Acedo-Valdez et al., 2017; Pimentel-Acosta et al.,

345 2019). However, this is the first work that examine the efficacy of Argovit-4 (AgNPs-based

346 formulation) as a potential antiviral additive in feed to protect the health of shrimp L. vannamei 347 against WSSV.

348 In order to evaluate the protective effect of AgNPs on shrimp against WSSV, firstly, we 349 determinate that 7 SID $_{50}$ was the minimum effective dose to generate $100 \%$ shrimp mortality 350 according to WSSV inoculum used (bioassay 1) and then, we preincubated infectious WSSV 351 inoculums (calibrated to $7 \mathrm{SID}_{50}$ ) with Argovit-4 at different concentrations, which were subsequently intramuscularly injected in shrimp (bioassay 2). Our results indicated that WSSV

353 354 355 infectivity is drastically affected due to a delay in the onset of clinical signs and mortality in a manner dose-dependent ( $<<0.05$ ) (Figure 2), compared with that observed in the control (WSSV without Argovit-4). Some authors have observed that silver nanoparticles interaction with envelope glycoproteins of virus can inhibit post-entry stages during replication cycle (Rogers et al., 2008; Lara et al., 2010; Borrego et al., 2016). Elechiguerra et al. (2005) suggested that AgNPs undergo specific interaction with HIV-1 due to their affinity to disulfide bonded regions (thiol groups provided in viral envelope protein domains). While, Lara et al. (2010) postulated that silver nanoparticles not only bind to the viral protein, but can also structurally modify it through the denaturing of disulfide-bound domain. Hence, we hypothesize that AgNPs could interact with WSSV envelope proteins (e.g. VP28; Tang et al., 2007) and block the specific binding to membrane proteins of shrimp host cells. This can be seen in our results of the ability of AgNPs to decrease residual infectivity of viral particles after 60 minutes of incubation, as described by Lara et al. (2010). Nevertheless, further research is needed to elucidate the antiviral mechanism of silver nanoparticles against WSSV.

Recently, Juarez-Moreno et al. (2017) reported that prophylactic doses 50 ng/g Argovit ${ }^{\circledR}$ (AgNPs-based formulation) administered by intramuscular route in infected shrimp with WSSV evinced a rate survival of $80 \%$ without toxic effects after $96 \mathrm{~h}$ post infection. While, OchoaMeza et al. (2019) showed evidence that a single therapeutic dose $1.2 \mu \mathrm{g} / \mathrm{g}$ AgNPs can delay the onset of clinical signs and enhance the response of shrimp immune system without toxic effects in healthy shrimps. However, this results are not comparable with Juarez-Moreno et al. (2017) and Ochoa-Meza et al. (2019) in effectiveness, due to the different: (1) AgNP preparations used, 
374 (2) weights of the shrimp and, (3) routes of exposure; considering that intramuscular

375 administration is impractical in aquaculture due to the enormous quantity of organisms that are 376 need to be treated (Kumar \& Roy, 2017).

377 The administration by feeding represents the most practical prophylactic or therapeutic method

378 for in situ shrimp culture (Alvarez-Sanchez et al., 2017). Therefore, we prepared feed

379 supplemented with Argovit-4 at 10,100 and $1000 \mu \mathrm{g} / \mathrm{g}$ doses and determined their effects on

380 shrimp health or mortality (bioassay 3). Our results showed no obvious toxicity effects on the

381 behavioural activity of shrimp in the form of erratic swimming, changes in feeding rate, atypical

382 body colour body, and increased mortality ( 1 shrimp death) in all treatments by the oral route.

383 The lack of mortality and clinical signs can be explained by the structural design of Argovit ${ }^{\circledR}$

384 nanoparticles having been approved by sanitary international organizations for their use in 385 veterinary and medical applications (Vazquez-Muñoz et al., 2014; Bogdanchikova et al., 2016;

386 Borrego et al., 2016).

387 Despite the potential of AgNPs as antimicrobial agent, in aquaculture industry, concerns remain

388

389

390

391

392

393

394

395

396

397

398

399

400

401

402

403

404 regarding the potential negative impact to the marine and freshwater environment. However, to date, there have not been clear the in vivo toxicity of silver nanoparticles in marine environment, as the effects depend on AgNP properties (particle size, surface area, shape), concentration, AgNP colloidal stability, aggregation grade, sedimentation, and on the amount and species of products yielded from chemical interactions between AgNPs and other variables (Fabrega et al., 2011; Sharma et al., 2019; Pimentel-Acosta et al., 2019),

It is important to clarify that Argovit-4, given its recent design, still does not present toxicity reports with which this AgNP should be better studied in terms of its safety if it is intended to apply to animals for human consumption and in turn study bioaccumulation in the same shrimp and in the ecotoxicological environment. We have presented in this research some results of AgNP exposure considering only the acute toxic response, that is, in the short term. This is because the antiviral activities observed are a consequence of the application of a single dose. The main reason why a chronic toxicological study was not performed is precisely because of the observed antiviral effect. Fabrega et al. (2011), points out that invertebrates such as water flea Daphnia pulex, acute and chronic toxicity studies do not generate bioaccumulation, although other authors point out that in the event that AgNPs accumulate in the gills, they do not have harmful side effects (Xiang et al., 2019), however, this could dependent of administered doses 
405 (Monfared et al., 2015). It is important to mention that more experiments should be carried out to 406 consider the possibility of applying this nanoparticular design in the field. For example,

407 bioassays that generate enough information to evaluate the bioaccumulation of flora and fauna 408 accompanying the bodies of water where the shrimp are raised.

409 To determine the protective properties of Argovit-4 supplemented in feed against WSSV, the 410 results of bioassay 4 indicate that the $1000 \mu \mathrm{g} / \mathrm{g}$ treatment provided the best protective effect in 411 shrimp against the inoculum of WSSV by the oral route than by injection (Fig. 3). This result 412 was probably due to the high bioavailability of the silver nanoparticles in the digestive tract, 413 which allowed the AgNPs-virus interactions to improve and promote entry by clathrin-mediated 414 receptor routes (Coutiño, Ávila-Lagunes \& Arroyo-Helguera, 2017). This is the first study that 415 describes the use of AgNPs as an antiviral additive in feed against WSSV. In recent years, the 416 use of metallic nanoparticles in aquaculture has been increased, for example in fish. For Clarias 417 gariepinus, selenium nanoparticles (SeNPs) at a $680 \mu \mathrm{g} / \mathrm{g}$ dose was observed to improve feeds 418 by increasing the proportion of fish food nutrients that pass across the gut tissue (Chris, Sing \& 419 Agarwal, 2018). For Clarias batrachus, it was also shown that iron nanoparticles (FeNPs) at a $420400 \mu \mathrm{g} / \mathrm{g}$ dose is sufficient to ensure the growth and health of fish (Akter et al., 2018).

421 Previous studies have demonstrated that because metallic nanoparticles are foreign elements to 422 organisms, they can be recognized and internalized by immune system cells through different 423 routes according to their size and shape (Jiang et al., 2008; Coutiño, Ávila-Lagunes \& Arroyo424 Helguera, 2017; Dacoba et al., 2017; Boraschi et al., 2017). To test this possibility, and to 425 determine the immunostimulatory effect in the early stages by assessing the expression of 426 immune-relevant genes, bioassay 5 was performed in which shrimp were fed Argovit-4 at a $4271000 \mu \mathrm{g} / \mathrm{g}$ dose due to it being the therapeutic dose that best-protected shrimp against WSSV. 428 Five genes encoding immune-related proteins were examined at different time intervals in 429 shrimp haemocytes (PAP, Rab6, Crustin, PEN4, and proPO) by RT-qPCR analysis. PAP 430 (Phagocytosis-Activating Protein) and Rab6 have been shown to be associated with phagocytosis 431 in shrimp immune response (Deachamag et al., 2006; Zhao et al., 2011; Ye, Zong \& Zhang, 432 2012; Ye, Tang \& Zhang, 2012; Soto-Alcalá et al., 2019). Crustin and PEN4 are antimicrobial 433 peptides (AMPs) that participate in the humoural defence against pathogens or foreign particles 434 (Wang et al., 2010; Hirono et al., 2011), while proPO is an important humoural effector in innate 435 immunity, catalysing the upstream steps of melanization in shrimp and others invertebrates 
436 (Gollas-Galván, Hernández-Lopez \& Vargas-Albores, 1999; Wang et al., 2010; Amparyup,

437 Charoensapsri \& Tassanakajon, 2013). The expression of the genes encoding PAP, Rab6,

438 Crustin, and PEN4 in the treated shrimps showed no significant differences in the time intervals

439 proposed with respect to the control (feed without Argovit-4). The expression of the gene

440 encoding phagocytosis activating protein was not activated in samples from the silver

441 nanoparticle-treated shrimp compared to that observed in the control shrimp samples, suggesting

442 that the size of the particles is important, since this parameter facilitates their incorporation and

443 internalization in haemocytes. This observation is reinforced by the same observed behaviour of

444 the Rab6 gene, which participates in the endocytic pathway (Soto-Alcala et al., 2019), since its

445 expression was not altered at any time by the silver nanoparticles. On the other hand, peneaidins

446 are a family of antibacterial proteins that have recently been shown to contribute to the arrest of

447 WSSV-type viral particles. However, the expression of the PEN4 gene was not altered with

448 respect to the time recorded from zero to 48 hours, which indicates that the AgNPs do not

449 interact with the effectors of this gene. The same pattern was observed for the expression of the

450 gene encoding Crustin, which has been shown to be activated in the first hours of WSSV

451 infection (Xiao et al., 2018; Sun, Wang \& Zhu, 2017). Taken together, the patterns of the four

452 assayed genes encoding PAP, Rab6, PEN3 and Crustin strongly suggests that the antiviral effect

453 of the nanoparticles occurs by a different pathway than antibacterial peptides or endocytic

454 phagocytosis.

455 The proPO system is one of the most studied in arthropods, where particles generated by cell

456 destruction and attacks by pathogenic organisms are coated by melanin via the oxidation of

457 phenols by the enzyme phenoloxidase, which are subsequently secreted as melanized corpuscles

458 (Amparyup, Charoensapsri \& Tassanakajon, 2013). The proPO gene encodes the phenoloxidase

459 precursor enzyme, with L. vannamei encoding LvproPO1 and LvproPO2 (Wang et al., 2010).

460 Interestingly, proPO has been shown to be active during WSSV infection (Abad-Rosales et al.,

461 2019). In this study, proPO gene expression exhibited a significant decrease at $48 \mathrm{~h}$ compared

462 with that observed in the control. Several authors have reported that during infection by WSSV,

463 the virions are not covered by melanin due to the participation of at least two viral proteins

464 identified in P. monodon. wsv164 interacts directly with PmproPO1 and PmproPO2 (Sangsuriya

465 et al., 2018), probably for an alternative route of infection. Similarly, the WSSV453 protein

466 interacts with the proPO activating enzyme 2 (PmPPAE2), which could explain the observed 
467 decrease in the expression of the proPO gene due to the presence of AgNPs, taking into account

468

469

470

471

472

473

474

475

476

477

478

479

480

481

482

483

484

485

486

487

488

489

490

491

492

493

494

495

that no challenge against WSSV was performed in this experiment (Sutthangkul et al., 2015;

Sutthangkul et al., 2017). Taken together, these results suggest that Argovits-4 does not induce the expression in of the assayed early stage immune-related genes, suggesting that the antiviral activity or immunostimulation by AgNP involves a different route to the endocytic pathway. A previous study by our group (Ochoa-Meza et al., 2019) reported that the LGBP and Cu,ZnSOD genes are negatively deregulated by the presence of AgNPs (Argovit $\AA$ ), which suggested that there must be a path for the internalization of the nanoparticles and the activation of the immune system of haemocytes. However, such a path does not require the participation of any of the five genes analysed in this study.

\section{Conclusions}

In this study, we explored whether a new AgNP formulation (Argovit-4), which replaced Argovit ${ }^{\circledR}$, has similar properties to protect and immunostimulant shrimp, allowing them to avoid infection by the white spot virus without causing toxic effects. In addition, we assessed if the expression of some genes immune system-related suggested a common means of activation.

1. Decreased or high concentrations of Argovit-4 nanoparticles do not generate mortality by causing toxicity towards shrimp.

2. The mixture of WSSV-Argovit-4 was capable of decreasing the mortality of shrimp by at least $50 \%$ by intramuscular administration.

3. Argovit-4 included in feed could be used to prevent infection by WSSV and can be considered a safe candidate to safeguard aquaculture systems in the future.

4. The zero expression of the PAP, Rab6, PEN4 and Crustin genes, suggest that the antiviral activity of Argovit-4 does not include any of the mechanisms by which such genes perform their function in the immune system of L. vannamei.

5. The late down regulation of proPO gene expression, suggests that the antiviral activity of Argovit-4, could to modify a different and unknown route to inhibit a WSSV infection.

\section{Acknowledgements}


496 For technical support: Rene R. Rebollar Prudente from the Biotechnological Marine Organism 497 Laboratory at the Northwest Biological Research Center (CIBNOR), and Carina Gámez Jimenez, 498 from the Biology and Biochemistry Laboratory of Centro de Investigaciones Interdisciplinarias 499 para el Desarrollo Integral Regional del Instituto Politécnico Nacional (CIIDIR-IPN), for all the 500 facilities and technical support during the experiments.

501

502 Funders

503 This study was supported by the National Council of Science and Technology (CONACyT), 504 Mexico, through grant No. 258607 and the Tomsk Polytechnic University Competitiveness 505 Enhancement Program project VIU-RSCBMT-65/2019. CONACYT CRQ-Scholarship: 493589.

506

\section{Competing interest}

508 The authors declare that there are no competing interests

509

\section{Author contributions}

511 Romo Quiñonez CR. PhD student. Performed all of the experiments.

512 Alvarez Sanchez AR. Participated in the experimental design and the discussion of the results.

513 Alvarez Ruiz P. Participated in the design and execution of the experiments and advised on the 514 analysis of molecular techniques. Co-director of the $\mathrm{PhD}$ student.

515 Chavez Sanchez MC. Leader of the global project and participated in the discussion of results 516 and the draft of the paper.

517 Bogdanchikova N. (nina@cnyn.unam.mx) Provided the AgNPs and participated in the writing of 518 the paper, providing information regarding the chemical properties of Argovit-4.

519 Pestryakov A. Designed the new AgNPs (Argovit-4) and provided important data for its 520 management.

521 Mejia Ruiz CH. Project leader in the management of AgNPs for their application in shrimp.

522 Participated in the experimental design, analysed results and the final manuscript. Principally

523 responsible for the paper and co-director of the PhD student.

524

525

References

526 
527 Abad-Rosales SM, Frías-Espericueta MG, Romero-Bernal OG, Lozano-Olvera R, Garcia-Gasca 528 SA, Montoya-Rodriguez L. and Voltolina D. 2019. White spot syndrome virus (WSSV) 529 infection and immunity responses in white shrimp (Litopenaeus vannamei) exposed to

530

531

532

533

534

535

536

537

538

539

540

541

542

543

544

545

546

547

548

549

550

551

552

553

554

555

556 sublethal levels of metals. Aq. Res. 50:758-764. DOI: 10.1111/are.13932

Acedo-Valdez MR, Grijalva-Chon JM, Larios-Rodríguez E, Maldonado-Arce AD, MendozaCano F, Sanchez-Paz JA, Castro-Longoria R. 2017. Antibacterial effect of biosynthesized silver nanoparticles in Pacific white shrimp Litopenaeus vannamei (Boone) infected with necrotizing hepatopancreatitis bacterium (NHP-B). Latin American Journal of Aquatic Research 45(2):421-430. DOI: 10.3856/vol45-issue2-fulltext-17

Akter N, Alam J, Jewel AS, Khatun S, Akter S. 2018. Evaluation of dietary metallic iron nanoparticles as feed additive for growth and physiology of Bagridae catfish Clarias batrachus (Linnaeus, 1758). International Journal of Fisheries and Aquatic Studies 6(3):371-377.

Álvarez-Ruiz P, Mejía-Ruiz CH, Magallón-Barajas FJ, Escobedo-Bonilla CM. 2013. Silencing Pacific white shrimp, Litopenaeus vannamei LvRab7 reduces mortality in brooders challenged with white spot syndrome virus. Aquac. Res. 44:772-782. DOI: 10.1111/j.13652109.2011.03084.x

Álvarez-Sánchez AR, Romo-Quiñonez C, Rosas-Quijano R, Reyes AG, Barraza A, Magallón F, Angulo C, Mejía CH. 2018. Production of specific dsRNA against white spot syndrome virus in the yeast Yarrowia lipolytica. Aquac. Res. 49:480-491. DOI: 10.1111/are.13479

Amparyup P, Charoensapsri W, Tassanakajon A. 2013. Prophenoloxidase system and its role in shrimp immune responses against major pathogens. Fish \& Shellfish Immunology 34(4):990-1001. DOI: 10.1016/j.fsi.2012.08.019

Apun-Molina JP, Robles-Romo A, Álvarez-Ruiz P, Santamaria-Miranda A, Arjona O, Racotta IS. 2017. Influence of stocking density and exposure to white spot syndrome virus in biological performance, metabolic, immune, and bioenergetics response of whiteleg shrimp Litopenaeus vannamei. Aquaculture 47:528-537. DOI: 10.1016/j.aquaculture.2017.06.027

Barakat KM, El-Sayed HS, Gohar YM. 2016. Protective effect of squilla chitosan-silver nanoparticles for Dicentrarchus labrax larvae infected with Vibrio anguillarum. International Aquatic Research 8(2):179-189. DOI: 10.1007/s40071-016-0133-2 
557 Baram-Pinto D, Shukla S, Perkas N, Gedanken A, Sarid R. 2009. Inhibition of herpes simplex $558 \quad$ virus type 1 infection by silver nanoparticles capped with mercaptoethane sulfonate.

559

560

561

562

563

564

565

566

567

568

569

570

571

572

573

574

575

576

577

578

579

580

581

582

583

584

585

Bioconjugate Chemistry 20(8):1497-1502. DOI: 10.1021/bc900215b

Bello-Bello J, Spinoso-Castillo J, Arano-Avalos S, Martínez-Estrada E, Arellano-García M, Pestryakov A, Toledano-Magaña Y, García-Ramos JC, Bogdanchikova N. 2018. Cytotoxic, Genotoxic, and Polymorphism Effects on Vanilla planifolia Jacks ex Andrews after LongTerm Exposure to Argovit ${ }^{\circledR}$ Silver Nanoparticles. Nanomaterials 8(10):754. DOI: 10.3390/nano8100754

Boraschi D, Italiani P, Palomba R, Decuzzi P, Duschl A, Fadeel B, Moghimi SM. 2017. Nanoparticles and innate immunity: new perspectives on host defence. Seminars in Immunology 3:33-51. DOI: 10.1016/j.smim.2017.08.013

Bustillo M, Escobedo C, Sotelo R. 2009. Revisión de patogénesis y estrategias moleculares contra el virus del síndrome de la mancha blanca en camarones peneidos. Revista de Biologia Marina y Oceanografia 1-11. DOI: 10.4067/S0718-19572009000100001

Chris UO, Singh NB, Agarwal A. 2018. Nanoparticles as feed supplement on Growth behaviour of Cultured Catfish (Clarias gariepinus) fingerlings. Materials Today: Proceedings 5(3):9076-9081. DOI: 10.1016/j.matpr.2017.10.023

Coutiño EMR, Lagunes-Ávila L, Arroyo-Helguera O. 2017. Las nanopartículas de plata: mecanismos de entrada, toxicidad y estrés oxidativo. Revista de Educación Bioquímica 36(2):39-54.

Dacoba TG, Olivera A, Torres D, Crecente-Campo J, Alonso MJ. 2017. Modulating the immune system through nanotechnology. Seminars in Immunology 34:78-102. DOI: 10.1016/j.smim.2017.09.007

Dananjaya SHS, Godahewa GI, Jayasooriya RGPT, Lee J, De Zoysa M. 2016. Antimicrobial effects of chitosan silver nano composites (CAgNCs) on fish pathogenic Aliivibrio (Vibrio) salmonicida. Aquaculture 450:422-430. DOI: 10.1016/j.aquaculture.2015.08.023

Deachamag P, Intaraphad U, Phongdara A, Chotigeat W. 2006. Expression of a phagocytosis activating protein (PAP) gene in immunized black tiger shrimp. Aquaculture 225:165-175. DOI: $10.1016 /$ j.aquaculture.2006.01.010 
586 Elechiguerra JL, Burt JL, Morones JR, Camacho-Bragado A, Gao X, Lara HH, Yacaman MJ.

587 2005. Interaction of silver nanoparticles with HIV-1. Journal of Nanobiotechnology 3:1-10.

588 DOI: $10.1186 / 1477-3155-3-6$

589 Esmaeillou M, Zarrini G, Rezaee MA, Mojarrad JS. 2017. Vancomycin Capped with Silver

590

591

592

593

594

595

596

597

598

599

600

601

602

603

604

605

606

607

608

609

610

611

612

613

614

Nanoparticles as an Antibacterial Agent against Multi-Drug Resistance Bacteria. Advanced Pharmaceutical Bulletin 7(3):479-483. DOI: 10.15171/apb.2017.058

Fabrega, J., Luoma, S.N., Tyler, C.R., Galloway, T.S., Lead, J.R., 2011. Silver nano- particles: behaviour and effects in the aquatic environment. Environ. Int. 37 (2): 517-531.

Flegel TW \& Sritunyalucksana, K. 2010. Shrimp Molecular Responses to Viral Pathogens. Marine Biotechnology 13(4):587-607. DOI: 10.1007/s10126-010-9287-x.

Galdiero S, Falanga A, Vitiello M, Cantisani M, Marra V, Galdiero M. 2011. Silver nanoparticles as potential antiviral agents. Molecules 16:8894-8918. DOI: 10.3390/molecules 16108894

Gollas-Galván T, Hernández-López J, Vargas-Albores F. 1999. Prophenoloxidase from brown shrimp (Penaeus californiensis) hemocytes. Comparative Biochemistry and Physiology Part-B 122(1):77-82. DOI: 10.1016/S0305-0491(98)10143-8

González-Fernández A, Peleteiro-Olmedo M, Lozano-Fernández T, Simon-Vázquez R, DiazFreitas B. 2012. Nanotecnología y Sistema inmunitario. In: Monografías Dr. Antonio Esteve "Nuevas perspectivas en Inmunoterapia", Ed Manel Juan. Barcelona: Fundación Dr. Antonio Esteve, 22-33.

Guemez-Sorhouet E, Villarreal H, Racotta IS, Naranjo J, Mercier L. 2019. Zootechnical and physiological responses of whiteleg shrimp (Litopenaeus vannamei) postlarvae reared in bioflocs and subjected to stress conditions during nursery phase. Aquaculture Research 114. DOI: $10.1111 /$ are.13994

Gutiérrez-Dagnino A, Luna-González A, Fierro-Coronado JA, Álvarez-Ruíz P, Flores-Miranda MC, Miranda-Saucedo S, Medina-Beltrán V, Escamilla-Montes R. 2015. Effect of inulin and fulvic acid on survival, growth, immune system, and WSSV prevalence in Litopenaeus vannamei. Latin American Journal of Aquatic Research 43(5):912-921. DOI: 10.3856/vol43-issue5-fulltext-11

Peer) reviewing PDF | (2019:07:39156:2:0:NEW 15 Nov 2019) 
615 Hirono I, Fagutao FF, Kondo H, Aoki, T. 2011. Uncovering the Mechanisms of Shrimp Innate 616 Immune Response by RNA Interference. Marine Biotechnology 13(4):622-628. DOI:

$617 \quad 10.1007 / \mathrm{s} 10126-010-9292-0$

618 Jiang W, Kim BYS, Rutka JT, Chan WCW. 2008. Nanoparticle-mediated cellular response is 619 size-dependent. Nature Nanotechnology 3(3):145-150. DOI: 10.1038/nnano.2008.30 620 Ji P, Yao C. and Wang Z. 2009. Immune response and gene expression in shrimp (Litopenaeus 621 vannamei) hemocytes and hepatopancreas against some pathogen-associated molecular 622 patterns. Fish \& Shellfish Immunology 27(4):563-570. DOI: 10.1016/j.fsi.2009.08.001 623 Kurtz, J. (2005). Specific memory within innate immune systems. Trends in Immunology 26(4). 624 DOI: $10.1016 /$ j.it.2005.02.001

625 Lara HH, Ayala-Nunez NV, Ixtepan-Turrent L, Rodriguez-Padilla C. 2010. Mode of antiviral 626 action of silver nanoparticles against HIV-1. J. Nanobiotech. 8:1. DOI: 10.1186/1477-3155$627 \quad 8-1$

628 Lara HH, Garza-Treviño EN, Ixtepan-Turrent L, Singh DK. 2011. Silver nanoparticles are 629 broad-spectrum bactericidal and virucidal compounds. J. of Nanobiotech. 30(9):1-8. DOI:

630 10.1186/1477-3155-9-30

Lu L, Sun RW, Chen R, Hui CK, Ho CM, Luk JM, Lau GK, Che CM. 2008. Silver nanoparticles 632 inhibit hepatitis B virus replication. Antiviral Therapy 13:253-262.

633 Khimmakthong U, Kongmee P, Deachamag P, Leggat U, Chotigeat W. 2013. Activation of an immune response in Litopenaeus vannamei by oral immunization with phagocytosis

635 activating protein (PAP) DNA. Fish \& Shellfish Immunology 34(3):929-38. DOI:

636 10.1016/j.fsi.2013.01.004

637 Kumar V, Roy S. 2017. Aquaculture Drugs: Sources, Active Ingredients, Pharmaceutic Preparations and Methods of Administration. J Aquac Res Development 8:510. DOI: $10.4172 / 2155-9546.1000510$

640

641

642

643

644

645
Martin GG, Quintero M, Quigley M, and Khosrovian H. 2000. Elimination of sequestered material from the gills of decapod crustaceans. Journal of Crustacean Biology 20(2):209217. DOI: $10.1163 / 20021975-99990032$

Mejía-Ruíz CH, Vega-Peña S, Álvarez-Ruiz P, Escobedo-Bonilla CM. 2011. Double-stranded RNA against white spot syndrome virus (WSSV) $v p 28$ or $v p 26$ reduced susceptibility of Litopenaeus vannamei to WSSV, and survivors exhibited decreased susceptibility in 
646

647 subsequent re-infections. Journal of Invertebrate Pathology 107: 65e68. DOI: 10.1016/j.jip.2011.02.002

648 Meneses-Márquez JC, Hamdan-Partida A, Monroy-Dosta MC, Castro-Mejía J, Bustos-Martínez 649 JA. 2018. Silver nanoparticles applications (AgNPS) in aquaculture. International Journal $650 \quad$ of Fisheries and Aquatic Studies 6:5-11.

651 Monfared AL, Bahrami AM, Hosseini E, Soltani S, Shaddel M. 2015. Effects of Nano-particles 652 on Histo-pathological changes of the fish. J Environ Health Sci Eng. 13: 62. DOI:

$653 \quad 10.1186 /$ s40201-015-0216-9

654 Morales-Covarrubias MS, García-Aguilar N, Bolan-Mejía MDC, Puello-Cruz AC. 2016.

655 Evaluation of medicinal plants and colloidal silver efficiency against Vibrio

656 parahaemolyticus infection in Litopenaeus vannamei cultured at low salinity. Diseases of 657 Aquatic Organisms 122(1):57-65. DOI: 10.3354/dao03060

658 Mori Y, Ono T, Miyahira Y, Nguyen VQ, Matsui T, Ishihara M. 2013. Antiviral activity of silver 659

660 nanoparticle/chitosan composites against H1N1 influenza A virus. Nanoscale Research

661

662

663

664

665

666

667

668 Letters 8(1):93. DOI: 10.1186/1556-276X-8-93

Parveen S, Misra R, Sahoo SK. 2012. Nanoparticles: a boon to drug delivery, therapeutics, diagnostics and imaging. Nanomedicine 8:147-66. DOI: 10.1016/j.nano.2011.05.016

Pfaffl MW. 2003. Quantification strategies in real-time PCR. In: A-Z of quantitative PCR. La Jolla, CA, USA: International University Line, 87-112.

Pimentel-Acosta CA, Morales-Serna FN, Chavez-Sanchez MC, Lara HH, Pestryakov A, Bogdanchikova N, Fajer-Avila EJ. 2019. Efficacy of silver nanoparticles against the adults

669 and eggs of monogenean parasites of fish. Parasitology Research 118(6):1741-1749. DOI:

670

Reed LJ, Muench H. 1938. A simple method of estimating fifty per cent endpoints. Am. J. Epidemiol. 27(3):493-497. DOI: 10.1093/oxfordjournals.aje.a118408

672

Rogers JV, Parkinson CV, Choi YW, Speshock JL, Hussain SM. 2008. A preliminary

673 assessment of silver nanoparticle inhibition of monkeypox virus plaque formation.

674 Nanoscale Research Letters 3(4):129-133. DOI: 10.1007/s11671-008-9128-2

675

Sanchez-Martínez JG, Aguirre-Guzman G, Mejía-Ruíz H. 2007. White Spot Syndrome Virus in

676 cultured shrimp: A review. Aquaculture Research 38(13):1339-1354. DOI: 10.1111/j.1365-2109.2007.01827.x 
677 Sangsuriya P, Charoensapsri W, Sutthangkul J, Senapin S, Hirono I, Tassanakajon A, and

678

679

680

681

682

683

684

685

686

687

688

689

690

691

692

693

694

695

696

697

698

699

700

701

702

703

704

705

706

Amparyup P. 2018. A novel white spot syndrome virus protein WSSV164 controls prophenoloxidases, PmproPOs in shrimp melanization cascade. Dev. Comp. Imm. 86:109117. DOI: $10.1016 / j . d c i .2018 .05 .005$

Sharma VK, Sayes CM, Guo B, Pillai S, Parsons JG, Wang C, Yan B, Ma X. 2019. Interactions between silver nanoparticles and other metal nanoparticles under environmentally relevant conditions: a review. Science of the Total Environmen 653:1042-1051. DOI: 10.1016/j.scitotenv.2018.10.411

Sritunyalucksana K, Soderhall K. 2000. The proPO and clotting system in crustaceans. Aquaculture 191:53-69. DOI: 10.1016/S0044-8486(00)00411-7

Soto-Alcalá J, Álvarez-Ruiz P, Audelo-Naranjo JM, Esparza-Leal M, Luis-Villaseñor IE, Estrada-Godínez JA, Luna-González A, Gámez-Jiménez C, Diarte-Plata G. 2019. Transcriptional response of immune-related genes in Litopenaeus vannamei post-larvae cultured in recirculating aquaculture systems with and without biofloc. Aq. Intern. 27:209225 DOI: 10.1007/s10499-018-0317-4

Speshock JL, Murdock RC, Braydich-Stolle LK, Schrand AM, Hussain SM. 2010. Interaction of silver nanoparticles with Tacaribe virus. J. Nanobiot. 8:19. DOI: 10.1186/1477-3155-8-19

Sun B, Wang Z, and F. Zhu. 2017. The crustin-like peptide plays opposite role in shrimp immune response to Vibrio alginolyticus and white spot syndrome virus (WSSV) infection. Fish \& Shellfish Immunology 66:487-496. DOI: 10.1016/j.fsi.2017.05.055

Sutthangkul J, Amparyup P, Eum JH, Strand MR, Tassanakajon A. 2017. Anti-melanization mechanism of the white spot syndrome viral protein, WSSV453, via interaction with shrimp proPO-activating enzyme, PmproPPAE2. Journal of General Virology. 98(4):69-778. DOI: 10.1099/jgv.0.000729

Tang X, Wu J, Sivaraman J \& Hew C. 2007. Crystal Structures of Major Envelope Proteins VP26 and VP28 from White Spot Syndrome Virus Shed Light on Their Evolutionary Relationship. J. Virol. 81(12) 6709-6717. DOI: 10.1128/jvi.02505-06

Tello-Olea M, Rosales-Mendoza S, Campa-Córdova AI, Palestino G, Luna-González A, ReyesBecerril M, Velazquez E, Hernandez-Adame L, Angulo C. 2019. Gold nanoparticles (AuNP) exert immunostimulatory and protective effects in shrimp (Litopenaeus vannamei) 
707

708

709

710

711

712

713

714

715

716

717

718

719

720

721

722

723

724

725

726

727

728

729

730

731

732

733

734

735

against Vibrio parahaemolyticus. Fish \& Shellfish Immunology 84:756-767. DOI: 10.1016/j.fsi.2018.10.056

Vazquez-Muñoz R, Avalos-Borja M, Castro-Longoria E. 2014. Ultrastructural analysis of candida albicans when exposed to silver nanoparticles. PLOS ONE 9(10):1-10. DOI: 10.1371/journal.pone.0108876

Verbruggen B, Bickley LK, van Aerle R, Bateman KS, Stentiford GD, Santos EM, Tyler CR. 2016. Molecular mechanisms of white spot syndrome virus infection and perspectives on treatments. Viruses 8(1):1-29. DOI: 10.3390/v8010023

Xiang QQ, Wang D, Zhang JL, Ding CZ, Luo X, Tao J Ling J, Shea D and Chen LQ. 2019. Effect of silver nanoparticles on gill membranes of common carp: Modification of fatty acid profile, lipid peroxidation and membrane fluidity. Environ. Poll. On-line. DOI.ORG/10.1016/J.ENVPOL.2019.113504

Xiao B, Fu Q, Niu S, Li H, Lü K, Wang S, Yin B, Weng S, Li C, He J. 2018. Penaeidins are a novel family of antiviral effectors against WSSV in shrimp. BioXRvi. Reprint Serv. Biol. DOI: $10.1101 / 467571$

Ye T, Tang W, Zhang X. 2012. Involvement of Rab6 in the regulation of phagocytosis against virus infection in invertebrates. Journal of Proteome Research 11:4834-4846. DOI:

\section{$10.1021 / p r 300274 k$}

Ye T, Zong R, Zhang X. 2012. The role of white spot syndrome virus (WSSV) VP466 protein in shrimp antiviral phagocytosis. Fish \& Shellfish Immunology 33:350-358. DOI: 10.1016/j.fsi.2012.05.017

Wang Y, Tseng CW, Lin HY, Chen I Chen YH, Chen YM, Chen TY, Yang HL. 2010. RNAi knock-down of the Litopenaeus vannamei Toll gene (LvToll) significantly increases mortality and reduces bacterial clearance after challenge with Vibrio harveyi. Dev. Comp. Immunol 34(1):49-58. DOI: 10.1016/j.dci.2009.08.003

Zhao Z, Jianga C, Zhang X. 2011. Effects of immunostimulants targeting ran GTPase on phagocytosis against virus infection in shrimp. Fish \& Shellfish Immunology 31:1013-1018. DOI: $10.1016 /$ j.fsi.2011.08.022 
Figure 1

WSSV-Inoculum title

Cumulative mortality of shrimp L. vannamei injected with three different WSSV doses by intramuscular route. Shrimps infected with 100, 10 and 7 SID. (f) Control negative shrimp treated with PBS. The results are presented as the mean \pm SD.

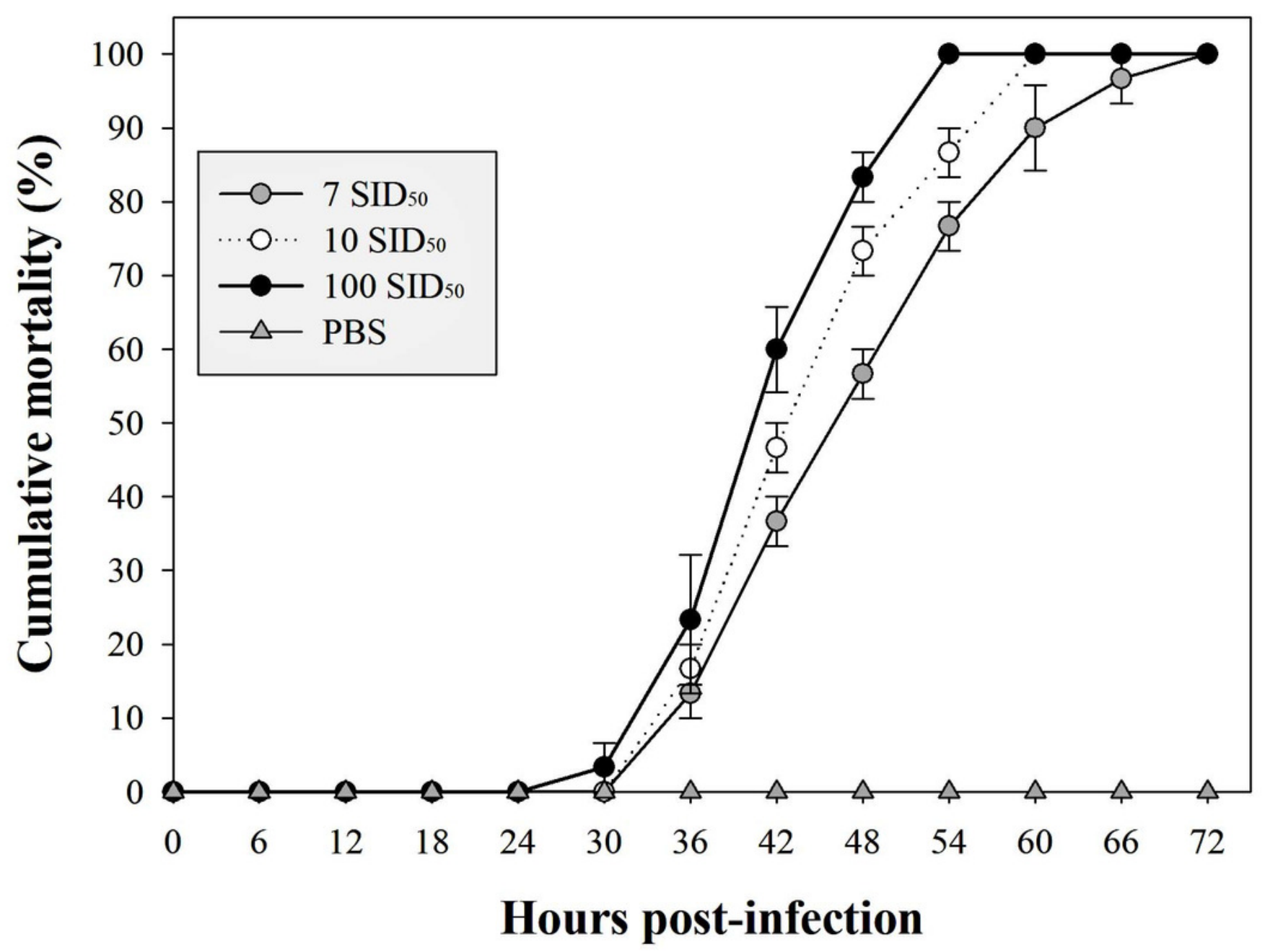


Figure 2

Effect of mixture Argovit-4/WSSV of different doses injected by intramuscular route

Cumulative mortality of $L$. vannamei juveniles: 40, 100, 200, $1000 \mathrm{ng} /(7)$ SID. (Control -) shrimp treated with PBS and were not infected; (Control +) shrimp treated with PBS and infected with WSSV inoculums. Statistical differences are represented by different letters $(p<0.05)$. Points are presented as the mean \pm SD.

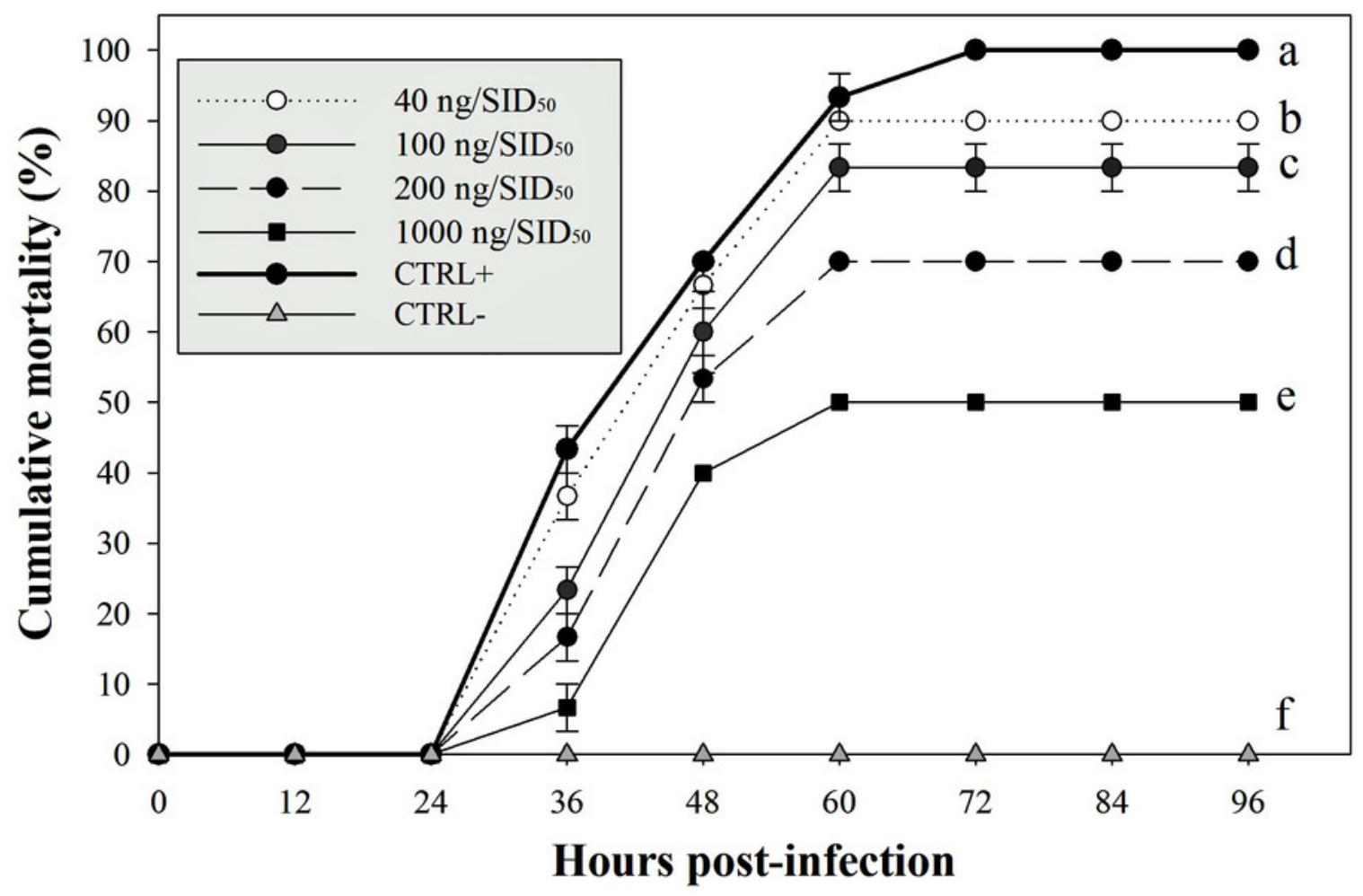




\section{Figure 3}

Effect of Argovit-4 supplemented in feed at different doses on cumulative mortality of $L$. vannamei juveniles

Shrimp nourished with Argovit-4 supplemented feed with concentration of silver: 10, 100, $1000 \mu \mathrm{g} / \mathrm{g}$. (Control +) shrimp fed only with WSSV inoculum. (Control -) shrimp fed with feed lacking Argovit-4 additive. Procedure sequence: at $0 \mathrm{~h}$ the feeding with Argovit-4 supplemented feed was executed for the first time; at $12 \mathrm{~h}$ feeding with Argovit-4 supplemented feed was performed for the second time and at $24 \mathrm{~h}$ feeding with WSSV inoculum (200 mg infected tissue per shrimp) was performed. After that, every $12 \mathrm{~h}$ the shrimps were fed with commercial feed. Statistical differences are represented by different letters $(p<0.05)$. The results are presented as the mean \pm SD. 


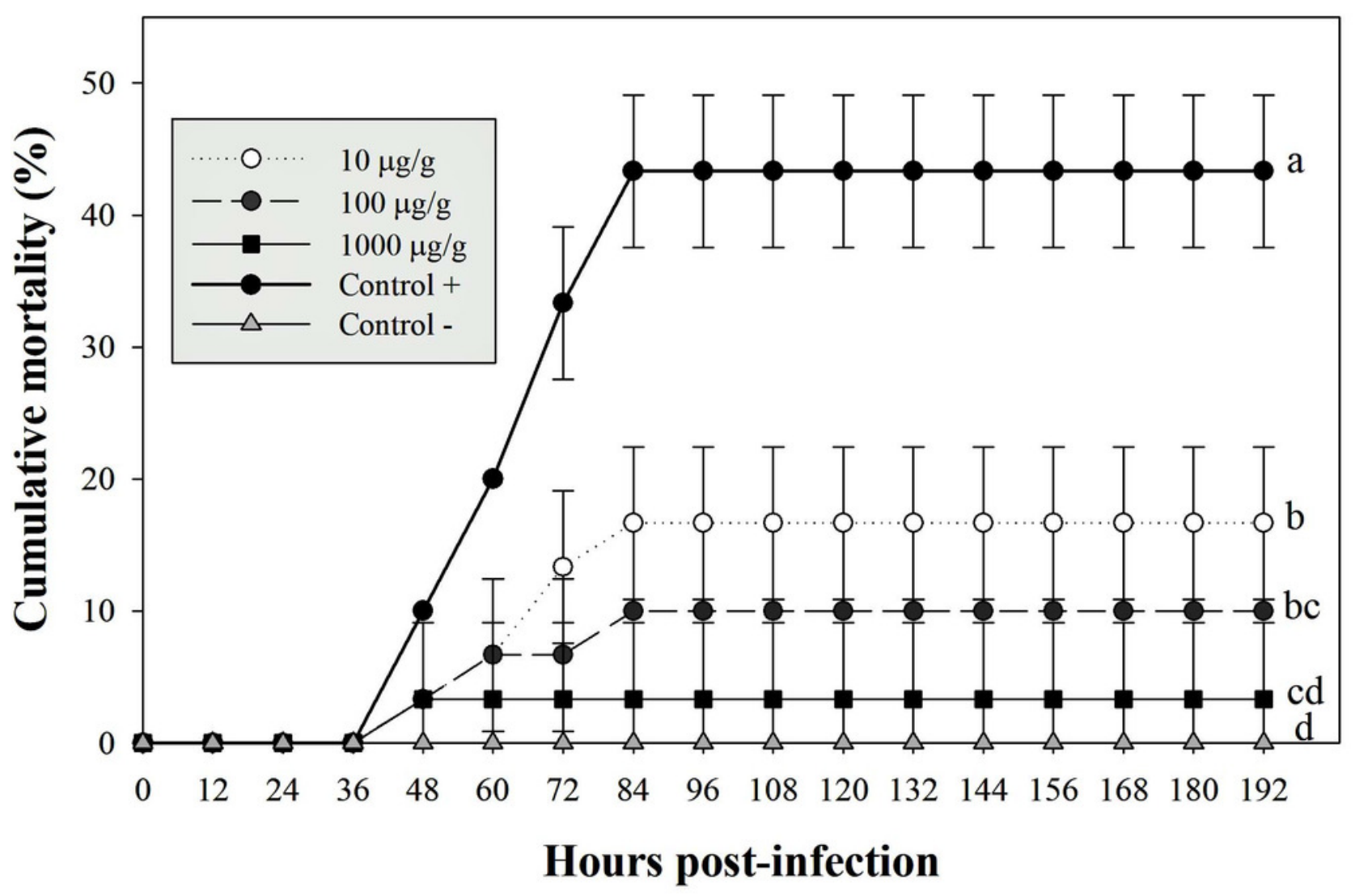


Figure 4

Relative expression of PEN4 and Crustin genes

The graphic show the RT-qPCR of; (A) Relative expression of PEN4 gene with no significant differences between AgNP treatment (black box) and control (white box); (B) Relative expression of Crustin gene, also no significant differences between AgNP treatment (black box) and control sample (white box). The data of the statistical analysis are represented in mean \pm standard error.

A

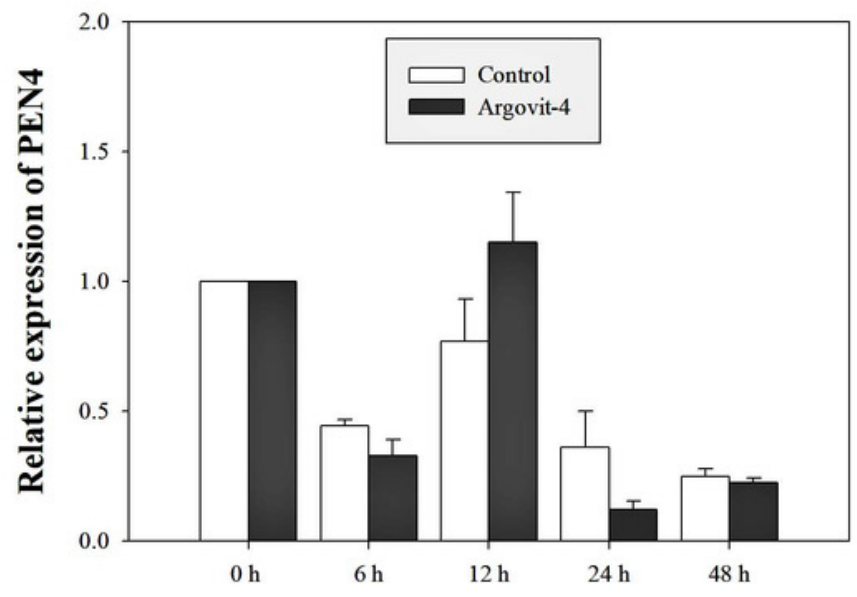

Hours post-treatment

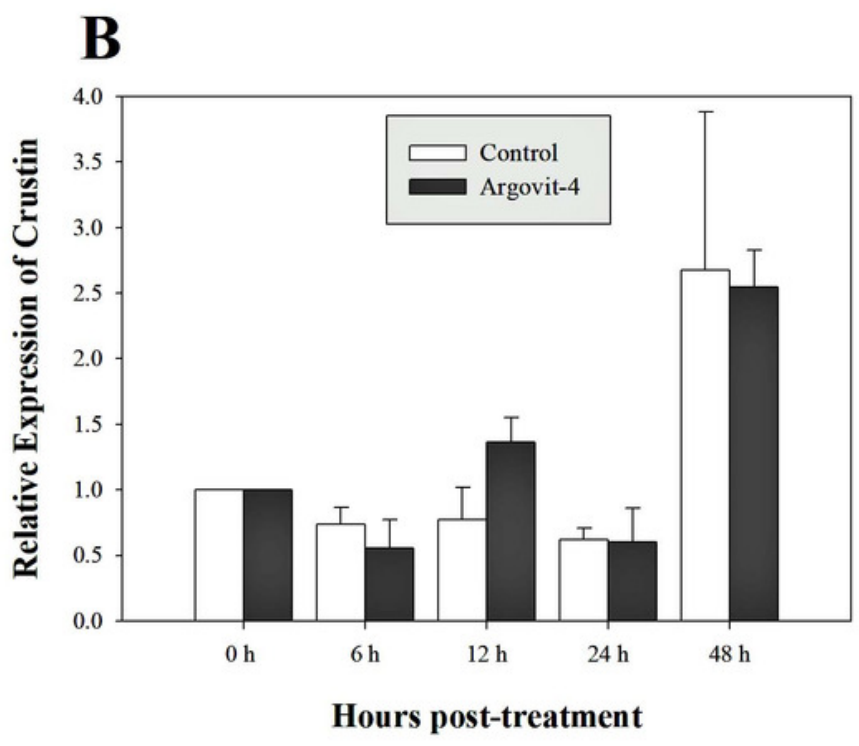

Hours post-treatment 
Figure 5

Relative expression of Rab6 and PAP genes.

The graphic show the RT-qPCR of; (A) Relative expression of Rab6 gene with no significant differences between AgNP treatment (black box) and control (white box); (B) Relative expression of PAP gene, also no significant differences between AgNP treatment (black box) and control sample (white box). The data of the statistical analysis are represented in mean \pm standard error.

A

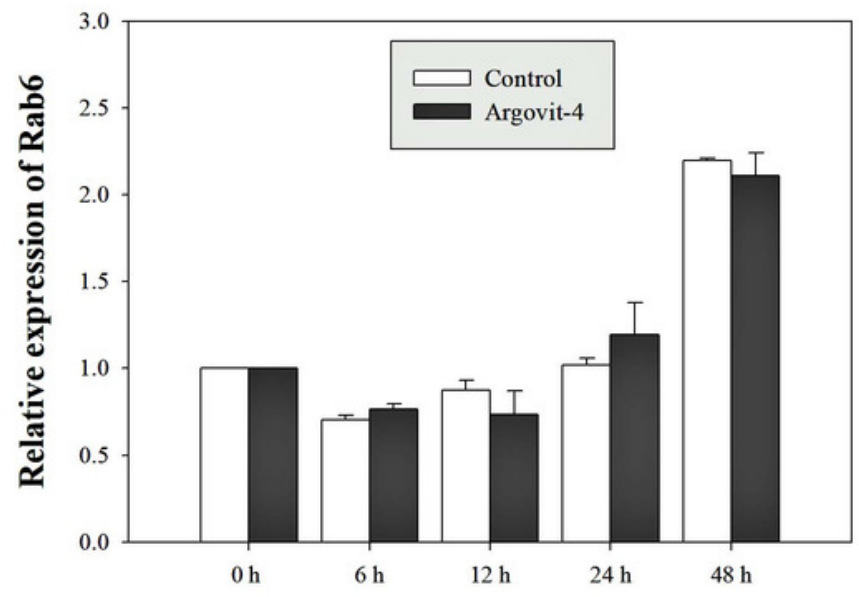

Hours post-treatment

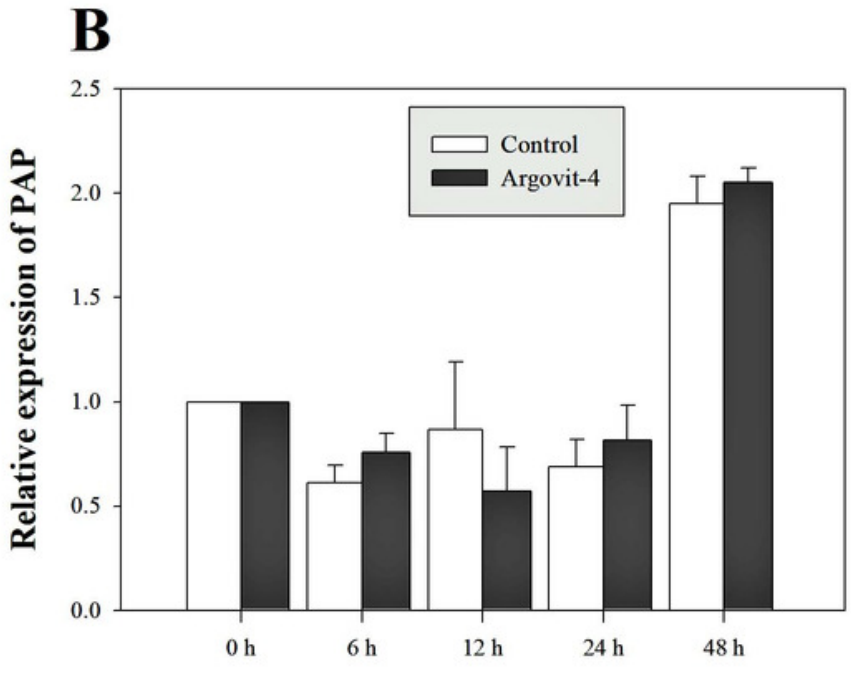

Hours post-treatment 
Figure 6

Relative expression of proPO gene

The graphic show the RT-qPCR of the relative expression of proPO gene with no significant differences between AgNP treatment (black box) and control (white box) only at $48 \mathrm{hrs}$. The data of the statistical analysis are represented in mean \pm standard error (Analysis test in text).

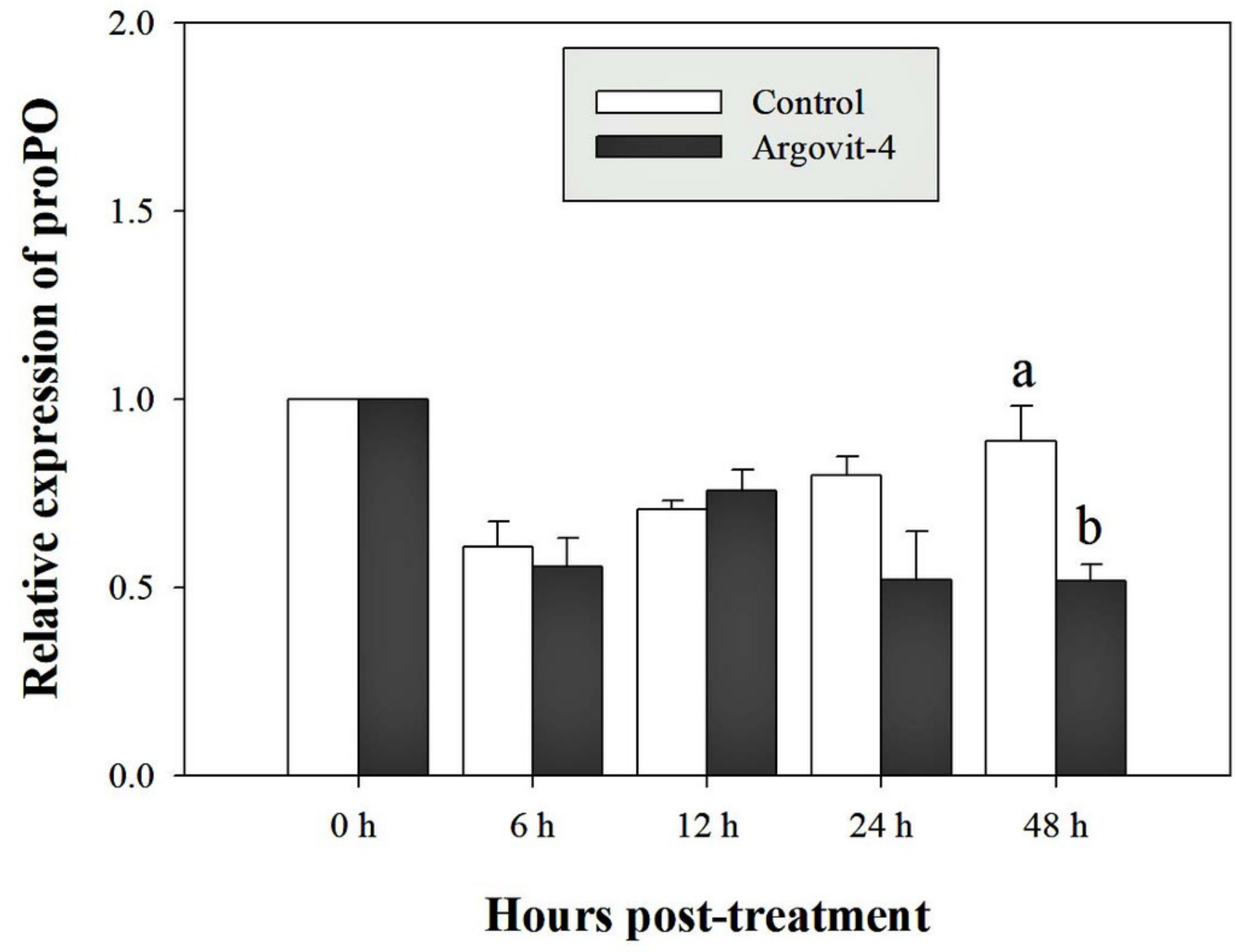




\section{Table 1 (on next page)}

Physicochemical Characteristics of silver nanoparticles

Physicochemical Characteristics of silver nanoparticles modified to Argovit-4 from JuarezMoreno et al., 2017. 


\begin{tabular}{|l|l|}
\hline Properties & Mean \\
\hline K- value & K30 \\
\hline PVP content & $18.8(\% \mathrm{wt})$. \\
\hline Metallic silver content & $1.2(\% \mathrm{wt})$. \\
\hline Silver nanoparticle morphology & spheroidal \\
\hline $\begin{array}{l}\text { Average diameter of metallic silver particles by TEM } \\
\text { data (nm) }\end{array}$ & $35 \pm 15$ \\
\hline Size interval of metallic silver particles by TEM data & 1 to $90(\mathrm{~nm})$ \\
\hline Hydrodynamic diameter: metallic Ag with PVP & $70(\mathrm{~nm})$ \\
\hline Zeta potential & $-15(\mathrm{mV})$ \\
\hline Surface plasmon resonance & $420(\mathrm{~nm})$ \\
\hline PVP structure by FTIR & Confirmed \\
\hline
\end{tabular}

1

2

3

4 
Table 2 (on next page)

Specific primers used

Specific primers used for PCR amplifications of immune system-related genes. 
1

\begin{tabular}{|c|c|c|c|}
\hline Genes & Primer sequences $\left(5^{\prime}-3^{\prime}\right)$ & $\begin{array}{c}\text { Amplification } \\
\text { Size (bp) }\end{array}$ & Reference \\
\hline ProPO & \begin{tabular}{|l|} 
Fw: CTGGGCCCGGGAACTCAAG \\
Rv: GGTGAGCATGAAGAAGAGCTGGA
\end{tabular} & 125 & Soto-Alcalá et al., 2018 \\
\hline PEN 4 & $\begin{array}{l}\text { Fw: GCCCGTTACCCAAACCATC } \\
\text { Rv: CCGTATCTGAAGCAGCAAAGTC }\end{array}$ & 106 & Wang et al., 2010 \\
\hline PAP & $\begin{array}{l}\text { Fw: CGAAGTTCAGGTTGTGCGTG } \\
\text { Rv: ACTGATGCACCATTGGCCTT }\end{array}$ & 126 & Soto-Alcalá et al., 2018 \\
\hline Rab 6 & \begin{tabular}{|l} 
Fw: GTTCCGCAGCCTTATTCCCT \\
Rv: ATCACTGCCTCGCTCTGTTC
\end{tabular} & 133 & Soto-Alcalá et al., 2018 \\
\hline Crustin & $\begin{array}{l}\text { Fw: GAGGGTCAAGCCTACTGCTG } \\
\text { Rv: ACTTATCGAGGCCAGCACAC }\end{array}$ & 157 & Wang et al., 2010 \\
\hline$\beta$-Actin & $\begin{array}{l}\text { Fw: CCACGAGACCACCTACAAC } \\
\text { Rv: AGCGAGGGCAGTGATTTC }\end{array}$ & 142 & Wang et al., 2007 \\
\hline
\end{tabular}

